\title{
Ionic liquid modified Pt/C electrocatalysts for cathode application in proton exchange membrane fuel cells
}

\author{
Huixin Zhang ${ }^{1,2}$, Jinying Liang1, Bangwang $\mathrm{Xia}^{2}$, Yang $\mathrm{Li}^{1}$, Shangfeng Du (凶) ${ }^{1}$ \\ 1 School of Chemical Engineering, University of Birmingham, Birmingham B15 2TT, UK \\ 2 School of Chemical Engineering, Hebei University of Technology, Tianjin 300130, China
}

(c) The Author(s) 2019. This article is published with open access at link.springer.com and journal.hep.com.cn

\begin{abstract}
The modification of $\mathrm{Pt} / \mathrm{C}$ catalyst by using ionic liquids to improve their catalyst activities has been reported by many researchers, but their practical behavior in operating fuel cells is still unknown. In this work, we study the ionic liquid modified $\mathrm{Pt} / \mathrm{C}$ nanoparticle catalysts within cathodes for proton exchange membrane fuel cells. The influence of the ionic liquid amount, adsorption times and dispersing solvents are investigated. The experiment results show the best performance enhancement is achieved through two-time surface modification with $2 \mathrm{wt}-\%$ ionic liquid solution. The mechanisms are explored with the attribution to the high oxygen solubility in the ionic liquid enabling an improved oxygen diffusion in micropores and to good hydrophobicity facilitating water expelling from the active sites in fuel cell operation.
\end{abstract}

Keywords ionic liquid, PEMFC, electrode, oxygen reduction reaction, electrocatalyst, adsorption

\section{Introduction}

Hydrogen represents one of the most promising forms of energy storage because of the simplicity compared to electrons and the high flexibility in producing. The proton exchange membrane fuel cell (PEMFC) has been demonstrated as the most efficient method to extract the stored energy from hydrogen due to their high power performance, low operation temperature, short start-up time and light weight [1]. Unfortunately, electrodes in PEMFCs today require significant amounts of platinum catalysts to drive the sluggish oxygen reduction reaction (ORR) at cathodes and the high cost plays great impact on their wide application and commercialization. Therefore, one of the major objectives in the PEMFC research has been the

Received December 1, 2018; accepted March 8, 2019

E-mail: S.Du@bham.ac.uk reduction of cost by improving both performance and durability of catalysts.

Ionic liquids (ILs) are molten ions conductive material below $100^{\circ} \mathrm{C}$, even around room temperature. Typical ILs exhibit high thermal stability $\left(>300^{\circ} \mathrm{C}\right)$, negligible vapor pressure, and non-flammability. They can also selfdissociate, resulting in a high ionic conductivity even in the absence of molecular solvent [2]. In 2010, Snyder et al. reported the use of a protic super hydrophobic, high oxygen solubility IL, [MTBD][beti], with nanoporous PtNi nanostructures [3]. The results showed the modification effectively reduced ORR over-potential and promoted reaction kinetics. Later, they carried out half-cell electrochemical measurement over IL modified commercial Pt/C catalysts in $\mathrm{O}_{2}$ saturated $0.1 \mathrm{~mol} \cdot \mathrm{L}^{-1} \mathrm{HClO}_{4}$ [4]. Increased performance was also observed and it was ascribed to the change of electronic and geometric structures of Pt catalyst surface, hydrophobicity and high $\mathrm{O}_{2}$ solubility of the protic IL. The IL integrated on surface Pt atoms led to a reduction in surface passivation, increasing the frequency of reactant attempts thus enhancing ORR kinetics. They also found when the volume of ILs equaled to the volume of pores, the performance improvement was sensitive to the use of the IL. Zhang et al. [5] then conducted research considering pore filling degree by ILs to explore the effect of porosity change on catalytic properties. The results showed that the half-wave potential of $\mathrm{Pt} / \mathrm{C}$ catalyst modified with IL $[\mathrm{MTBD}]\left[\mathrm{NTf}_{2}\right]$ was more positive than that of the pure catalyst. And this change positively varied with the pore filling degree in a low filling range. The half-cell liquid electrolyte measurement showed that the improvement did not change the reaction mechanisms of the ORR. A following work [6] demonstrated that there was essentially no difference in the reaction path of the catalyst before and after modification by ILs and the site blocking effect from ILs can also be ignored. Furthermore, the suppression of the IL modification on forming oxygenated species was clearly found. 
Compared to the clean environment for half-cell electrochemical measurement in pure liquid electrolyte, the situation in practical PEMFC devices is much different and complex [7]. Considering the well demonstrated improved catalytic activity by half-cell electrochemical measurement, here we study the behavior of IL modification for catalysts within operating PEMFCs. Commercial $\mathrm{Pt} / \mathrm{C}\left(20 \mathrm{wt}_{\mathrm{Pt}_{\mathrm{t}}} \%\right)$ nanoparticle catalysts modified with [MTBD] $\left[\mathrm{NTf}_{2}\right]$ on surface are incorporated into catalyst layers in cathodes for PEMFCs. By investigating the IL adsorption amount and times on catalyst surface, as well as IL dispersing solvent, considering the electrode surface morphology and fuel cell power performance, the original of the power performance improvement mechanisms is explored.

\section{Experimental}

\subsection{Sample preparation}

\subsubsection{Synthesis of IL [MTBD][NTf 2$]$}

The IL [MTBD] $\left[\mathrm{NTf}_{2}\right]$ was synthesized following the method reported in literature with some minor changes [8], and its chemical structure was verified by spectroscopy analyses. Equal molar ratios of 7-methyl-1,5,7-triazabicyclo [4.4.0] dec-5-ene (HMTBD, 98\%, Sigma-Aldrich) and bis(trifluoromethane) sulfonimide lithium salt $\left(\mathrm{LiNTf}_{2}\right.$, Sigma-Aldrich) were used. Typically, 5.2 g HMTDB was mixed with $10 \mathrm{~mL}$ of Millipore water and then neutralized using diluted $\mathrm{HNO}_{3}$ solution $((1+3) \mathrm{v} / \mathrm{v}$, from $70 \%$ $\mathrm{HNO}_{3}$, Fisher Scientific) to $\mathrm{pH}$ 7. Then, $9.7 \mathrm{~g} \mathrm{LiNTf}_{2}$ dissolved in $12 \mathrm{~mL}$ water was added into the above HMDB solution. The mixture was stirred overnight and viscous IL $[\mathrm{MTBD}]\left[\mathrm{NTf}_{2}\right]$ developed below the water. The product was separated, washed with water until neutral $\mathrm{pH}$ obtained. The IL was then dried under vacuum for $72 \mathrm{~h}$ at ambient temperature and prepared into a solution of $8 \mathrm{mg} \cdot \mathrm{mL}^{-1}$ with absolute isopropanol (IPA) or ethanol (depending on the experiment) and stored in a desiccator.

\subsection{2 $[\mathrm{MTBD}]\left[\mathrm{NTf}_{2}\right]$ modification of $\mathrm{Pt} / \mathrm{C}$ nanoparticle catalysts}

Firstly, $38.4 \mathrm{mg}$ commercial $\mathrm{Pt} / \mathrm{C}$ nanoparticle catalysts (20 wt-\% Pt loading, from Fuel Cell Store, USA) was dispersed in a designed amount of IPA based on the IL concentration required and sonicated in an ultrasonic bath for $10 \mathrm{~min}$. Then, $8 \mathrm{mg} \cdot \mathrm{mL}^{-1}[\mathrm{MTBD}]\left[\mathrm{NTf}_{2}\right]$ in IPA was added and then the total suspension volume was adjusted to $5 \mathrm{~mL}$ using IPA. To make the IL well dispersed on the surface of $\mathrm{Pt} / \mathrm{C}$ catalysts, the suspension was left with magnetic stirring for $3 \mathrm{~h}$ before standing in a vacuum desiccator until the volume reduced to $1 \mathrm{~mL}$. The resulted
$\mathrm{Pt} / \mathrm{C}$ with $[\mathrm{MTBD}]\left[\mathrm{NTf}_{2}\right]$, namely Pt/C@IL, was separated via centrifuge. In the research of adsorption times, the adsorption will be repeated according to the above process. After adsorption, to making catalyst ink for fuel cell electrode fabrication, the final Pt/C@IL were re-dispersed into $2 \mathrm{~mL}$ IPA in an ultrasonic bath for $15 \mathrm{~min}$. For all experiments with ethanol, IPA was replaced with ethanol for all steps above.

\subsection{Physical characterization}

Scanning electron microscopy (SEM) analysis of the catalyst electrode surface fabricated from the as-prepared Pt/C@IL was conducted with a HITACHI TM3030Plus microscope. X-ray diffraction (XRD) patterns were obtained with a Bruker D8 Discovery X-ray diffractometer using $\mathrm{Cu} K_{\mathrm{a}}$ radiation $(1.5418 \AA)$. X-Ray photoelectron spectroscopy (XPS) was acquired on an XPS spectrometer (VG Escalab 250xi) with a monochromated $\mathrm{Al} K_{\mathrm{a}}$ source.

\subsection{Membrane electrode assembly (MEA) preparation}

Sixteen $\mathrm{cm}^{2}$ catalyst electrodes were prepared with $\mathrm{Pt}$ and Nafion at a loading of 0.4 and $0.6 \mathrm{mg} \cdot \mathrm{cm}^{-2}$, respectively. The Pt/C@IL suspension in IPA (or ethanol) was mixed with $91.4 \mu \mathrm{L} 10 \%$ Nafion aqueous solution $(9.6 \mathrm{mg}$ Nafion) using ultrasonic bath for $30 \mathrm{~min}$ to make catalyst ink, which was then painted onto a $16 \mathrm{~cm}^{2}$ SIGRACET 39BC carbon paper gas diffusion layers to make gas diffusion electrodes (GDEs). Commercial Johnson Matthey GDEs with $\mathrm{Pt} / \mathrm{C}$ catalysts at a loading of $0.4 \mathrm{mg}_{\mathrm{Pt}} \cdot \mathrm{cm}^{-2}$ was used as anodes, on which a thin Nafion layer was painted at a loading of $0.6 \mathrm{mg} \cdot \mathrm{cm}^{-2}$. The two GDEs were then sandwiched at both sides of a $6 \mathrm{~cm} \times 6 \mathrm{~cm}$ Nafion 212 membrane, and hot pressed at $135^{\circ} \mathrm{C}$ under a pressure of $0.8 \mathrm{MPa}$ for two minutes to make MEAs.

\subsection{Fuel cell test}

The fabricated MEAs were tested with PaxiTech-BioLogic FCT-50S PEMFC test stand. Polytetrafluoroethylene sheet with a thickness of $254 \mu \mathrm{m}$ was used as gasket at both cathode and anode sides. The MEA was activated by a break-in at $0.6 \mathrm{~V}$ for $12 \mathrm{~h}$, and after that polarization curves were recorded at a scan rate of $2 \mathrm{mV} \cdot \mathrm{s}^{-1}$. The gas flow rates for fully humidified $\mathrm{H}_{2}$ and air were kept at a stoichiometry of 1.3/2.4, respectively. Electrochemical impedance spectroscopy (EIS) measurements were performed in the frequency range from $10 \mathrm{kHz}$ to $0.1 \mathrm{~Hz}$ with an amplitude of $10 \mathrm{mV}$. Cathode cyclic voltammograms (CVs) were recorded using an EZstat-Pro system integrated with the test stand. The cathode was fed with fully humidified pure nitrogen at $300 \mathrm{~mL} \cdot \mathrm{min}^{-1}$, and the anode was fed with fully humidified pure hydrogen at a flow rate of $120 \mathrm{~mL} \cdot \mathrm{min}^{-1}$ serving as both reference and counter 
electrode, also designated as a dynamic hydrogen electrode (DHE). Then the cathode potential was cycled between 0.05 and $1.2 \mathrm{~V}$ versus DHE at $20 \mathrm{mV} \cdot \mathrm{s}^{-1}$ for 3 cycles, and the third cycle was recorded. All the above mentioned tests were conducted at $80^{\circ} \mathrm{C}$ with fully humidified gases and the backpressure was 2 barg at both sides.

Catalytic activity under oxygen was measured according to the standard protocol defined by U.S. Department of Energy (DoE) $[9,10]$, considering the ohmic resistance correction and $\mathrm{H}_{2}$ crossover correction. The test was conducted in fuel cells at $80^{\circ} \mathrm{C}$ with fully humidified $\mathrm{H}_{2}$ and $\mathrm{O}_{2}$ at stoichiometric ratios of 2.0 at the anode and 9.5 at the cathode, respectively. The total pressure was $1.5 \mathrm{bar}$ (i.e., back pressure at $0.5 \mathrm{barg}$ ) at both sides for the whole testing. Cell resistances were determined by in situ EIS measurement at the high frequency range and used for resistance correction. The $\mathrm{H}_{2}$ crossover correction was processed by including the $\mathrm{H}_{2}$ crossover current densities measured at $0.6 \mathrm{~V}$ over a period of $30 \mathrm{~min}$ under the operating conditions (i.e., temperature and partial pressure) with fully humidified $\mathrm{H}_{2}$ and $\mathrm{N}_{2}$ purged at the anode and cathode, respectively. Catalyst activities were evaluated on the basis of ohmic resistance and $\mathrm{H}_{2}$ crossover corrected current densities.

\section{Results and discussion}

Due to the high viscosity and cluster size changing of ILs, their initial dispersion in solvent will significantly affect the solution properties and thus their surface modification behaviour over catalysts [11-15]. Following former knowledge obtained by other researchers [3-6,12,16-19], the IL coating was first conducted to $\mathrm{Pt} / \mathrm{C}$ catalysts with initial concentrations between $1 \%$ and $10 \%$ by 2 times surface modification process. SEM imaging analysis was conducted to observe the surface morphology of GDEs fabricated from Pt/C and Pt/C@IL catalysts to understand the influence of IL surface modification on the final electrode fabrication (Fig. 1). It can be seen that there is no obvious surface change to the GDEs from the unmodified and modified catalysts, at an initial IL concentration from $0 \%$ to $10 \%$. This is as expected because the IL finally coated onto the catalyst surface is not very high and will not affect too much the dispersion properties of catalyst in solvent in catalyst ink making process. The XRD patterns and XPS spectra of $\mathrm{Pt} / \mathrm{C}$ with various IL loadings are shown in Fig. 2. There is no obvious change observed to crystal structure and Pt element status except an increase F signal with XPS spectra caused by the increase IL amount. This also indicates that the IL modification of $\mathrm{Pt} / \mathrm{C}$ catalysts does not affect the final electrode fabrication process and a similar catalyst layer structure can still be achieved.

Figures 3(a) and 3(b) compare the polarization and power density curves measured for MEAs fabricated from
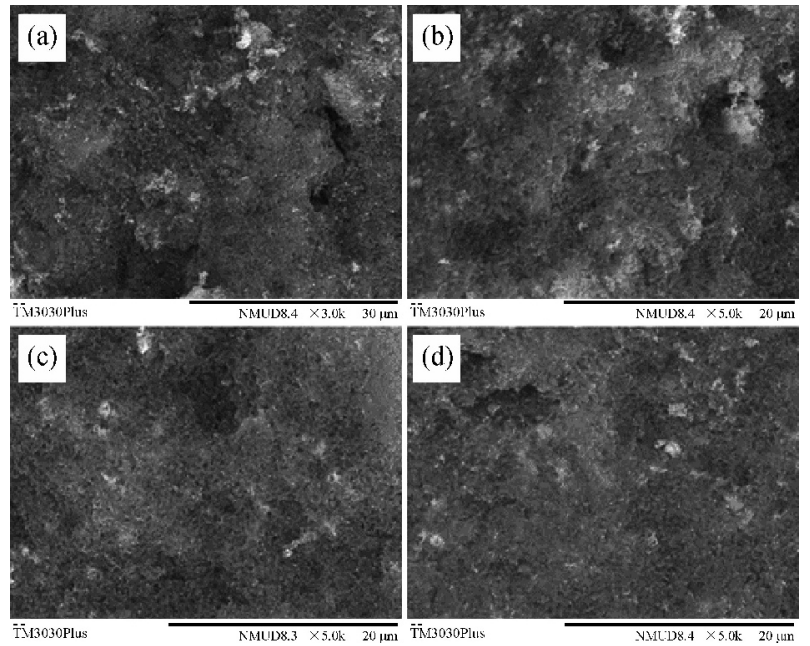

Fig. 1 Surface SEM images of GDEs made from unmodified and IL modified Pt/C catalysts: (a) no IL, (b) 2\% IL-2, (c) 5\% IL-2 and (d) $10 \%$ IL-2. The IL percentage is defined by the mass ratio of the IL to the $\mathrm{Pt} / \mathrm{C}$ catalyst in the surface modification process related to the IL concentration in the initial suspension, and-2 means the adsorption process was done for 2 times.

cathodes using Pt/C and Pt/C@IL catalysts. The MEAs with IL-modified cathodic catalysts exhibit much better power performances than that of the unmodified catalyst within the entire current density region studied and the improvement varies depending on the initial IL concentration. The highest power performance was obtained with $2 \%$ IL-2, increasing to $0.605 \mathrm{~W} \cdot \mathrm{cm}^{-2}$ from $0.337 \mathrm{~W} \cdot \mathrm{cm}^{-2}$ of the unmodified $\mathrm{Pt} / \mathrm{C}$, about 1.8 times higher. The improvement can be explained by two reasons as indicated by Snyder et al. [3,4] and Zhang et al. [5,6,16]: (i) for the catalyst nanoparticles without the IL, the pores on the catalyst surface can trap stagnant gas, forming inactive sites thus reduce the catalytic activities; (ii) the higher solubility of oxygen in IL [MTBD] $\left[\mathrm{NTf}_{2}\right]$ increases the oxygen concentration around the catalyst surface, and the thin IL layer facilitates the desorption of nonreactive species and reactants, as well as covers the defect sites on catalyst surface from oxidation, thus increasing the available sites for oxygen adsorption, playing an antioxidant role in fuel cell operation and improving the ORR kinetics. This mainly contributed to the low current density region. At the high current density region, due to the superhydrophobic property of IL $[\mathrm{MTBD}]\left[\mathrm{NTf}_{2}\right]$, the water produced in the reaction is expelled preventing them assembling on catalyst surface and providing more active sites, increasing the ORR frequency and minimizing the effect of mass transport. Thus, by IL surface modification, active sites are activated and ORR is accelerated, finally leading to boosted power performance in fuel cell operation. But, a further increase of the IL initial concentration above $2 \%$ results in a decrease of the power performance, declining to $0.550 \mathrm{~W} \cdot \mathrm{cm}^{-2}$ at $10 \% \mathrm{IL}-2$, 


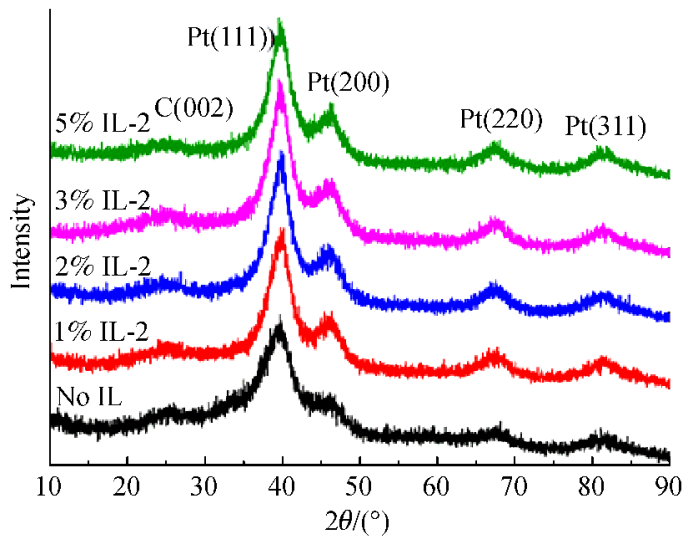

(a)

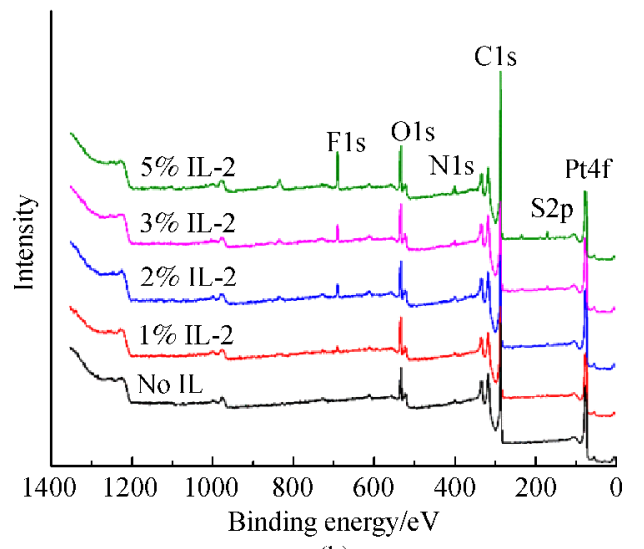

(b)

Fig. 2 (a) XRD patterns for Pt/C@IL with different initials of [MTBD]NTf ${ }_{2}$; (b) XPS spectra for Pt/C@IL with different initials of [MTBD]NTf 2.

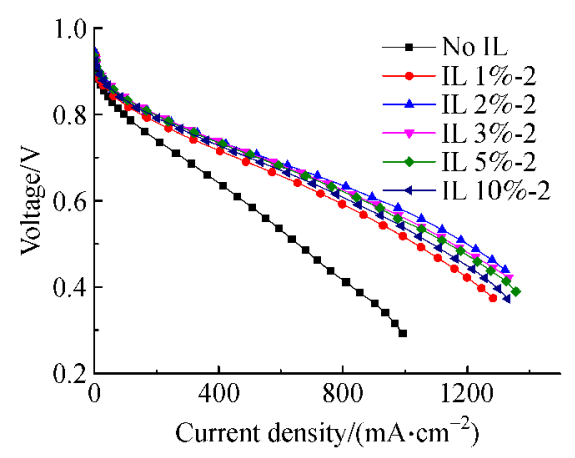

(a)

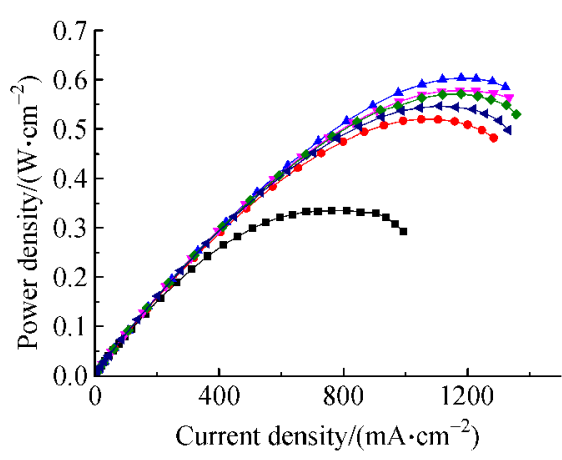

(b)

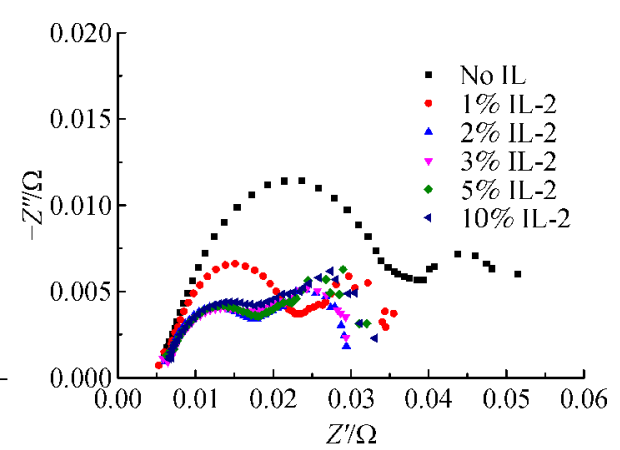

(c)

Fig. 3 (a) Polarization curves, (b) power density curves and (c) electrochemical impedance spectra under the operating voltage of $0.6 \mathrm{~V}$ of the MEAs fabricated from cathodes using Pt/C and Pt/C@IL catalysts.

which can be attributed to the large molecular cluster size of the IL solution at a higher concentration which further affects their coating behavior on the catalyst surface. A thicker IL layer is finally obtained on catalyst surface, which is not prone to oxygen diffusion and will partially blocking the pores between catalyst nanoparticles within the catalyst layer finally leads to a decrease of the electrode power performance in fuel cell operation [17-20]. This is different from conclusions that the site blocking effect from ILs can be ignored by half cell electrochemical measurement due to a large amount of water produced in fuel cell operation; and it can also be found that the optimal amount of the IL for surface modification in fuel cell electrodes is much lower compared to that reported by half cell electrochemical measurement $[5,6,16]$, further confirming the big difference between both activity evaluation methods [9,10]. EIS measurement was conducted to provide more insight into the electrode properties and the spectrum measured at $0.6 \mathrm{~V}$ is shown in Fig. 3(c). The intersection of the spectra on the real impedance-axis at the high frequency regime is attributed to uncompensated ohmic resistance, which is primarily from the ionic resistance of the membrane and interfacial contact resistance in MEAs. All MEAs show nearly the same value here due to the same membrane and test conditions used. With EIS, there are two semicircles; the first impedance semicircle is mainly contributed by the charge transfer resistance and the second one by mass transfer resistance. The diameter of the first impedance semicircle is reduced after the catalyst is modified with the IL, indicating the improvement of the charge transfer performance; that is, the catalytic activity of the IL modified $\mathrm{Pt} / \mathrm{C}$ becomes higher, as also confirmed by the polarization curves. With the increase of the IL amount, the second semicircle also keeps increasing, demonstrating an increased mass transfer resistance due to the partially blocking of the pores within the electrodes.

To further understand the enhancement mechanisms of IL modification to catalyst activities in fuel cell operation, cathode cyclic voltammetry measurement was performed to the PEMFCs. Compared with electrodes from Pt/C catalysts, the ones with Pt/C@IL all show a decrease in the $\mathrm{H}_{2}$ adsorption and desorption peaks between $0.05-0.4 \mathrm{~V}$. This is because the cover on the catalyst surface by the IL, which reduces the active sites available for the $\mathrm{H}_{2}$ adsorption although this surface cover has been confirmed 
accelerating ORR in fuel cell operation. This is consistent with the work conducted by Wang and Snyder with halfcell electrochemical measurement in liquid electrolyte $[4,5]$. To compare the mass activities for ORR after the IL modification, all PEMFCs were tested under oxygen following the standard of U.S DoE test protocol [9] and the results were shown in Fig. 4. This is to minimize the influence of mass transport loss due to nitrogen by using air. The original uncorrected, and IR and hydrogen crossover corrected polarization curves are shown in Figs. 4(b) and 4(c), respectively. Comparing the current density at $0.9 \mathrm{~V}$, the improvement of IL modification can be clearly observed. Fuel cells with the IL loading of $2 \%$, $3 \%$ and $5 \%$ exhibit a similar higher value compared with those of $1 \%$ and $10 \%$ IL loading, but $2 \%$ IL modified cell shows the largest current density at the region with the voltage $>0.9 \mathrm{~V}$, further demonstrating the best catalytic activity achieved. The mass activities at $0.9 \mathrm{~V}$ are displayed in Fig. 4(d) and 2\% IL modified electrode reaches 138 $\mathrm{mA} \cdot \mathrm{mg}_{\mathrm{Pt}}{ }^{-1}$, which is 1.7 times of $82 \mathrm{~mA} \cdot \mathrm{mg}_{\mathrm{Pt}}{ }^{-1}$ of unmodified one, indicating the enhanced effect by IL modification.

The IL-impregnation of the nano-particle $\mathrm{Pt} / \mathrm{C}$ can be considered as a kind of adsorption of [MTBD][NTf2] onto the porous $\mathrm{Pt} / \mathrm{C}$ surface. Therefore, the IL-uploading must have its favor conditions and effective capacity, affecting the adsorption equilibrium and kinetics. Therefore, the adsorption times of $2 \%$ IL was studied for Pt/C catalysts, and the resulted polarization curves are shown in Fig. 5. One time modification shows a lower polarization curve, but 3 times modification also slightly decreases the fuel cell power performance which might also caused by the blocking of pores with catalysts $[13,15,19-21]$. Therefore, two times of surface modification is still the optional choice for the $\mathrm{Pt} / \mathrm{C}$ catalyst system in PEMFC application.

Considered the specific dissolution behavior and interaction between its components, and strong hydrogen band effect, the medium of IL-adsorption and trace water within the solvent can also impair the dissociation and adsorption of IL onto the catalyst surface, affecting the access to

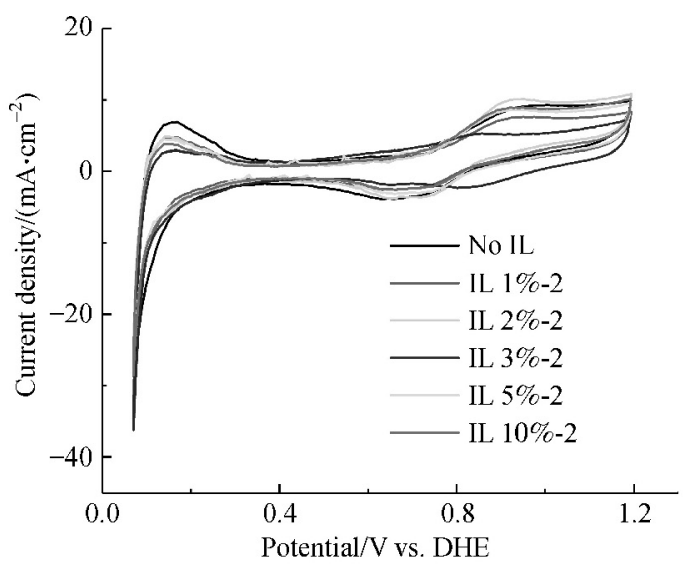

(a)

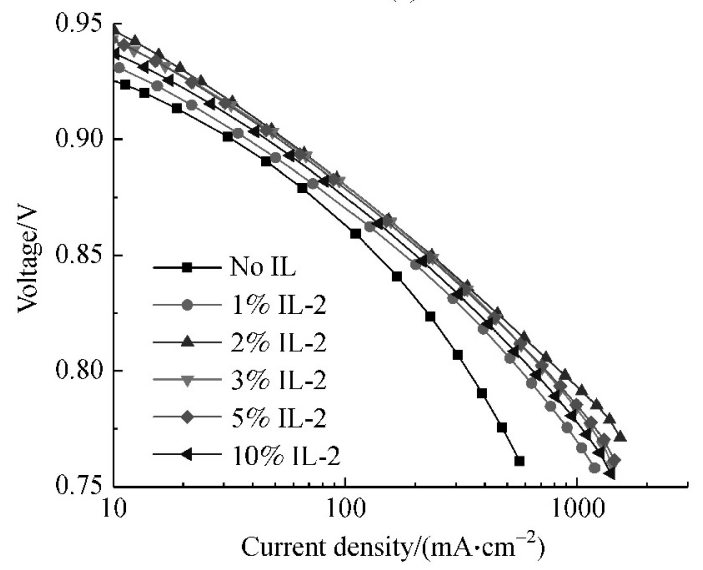

(c)

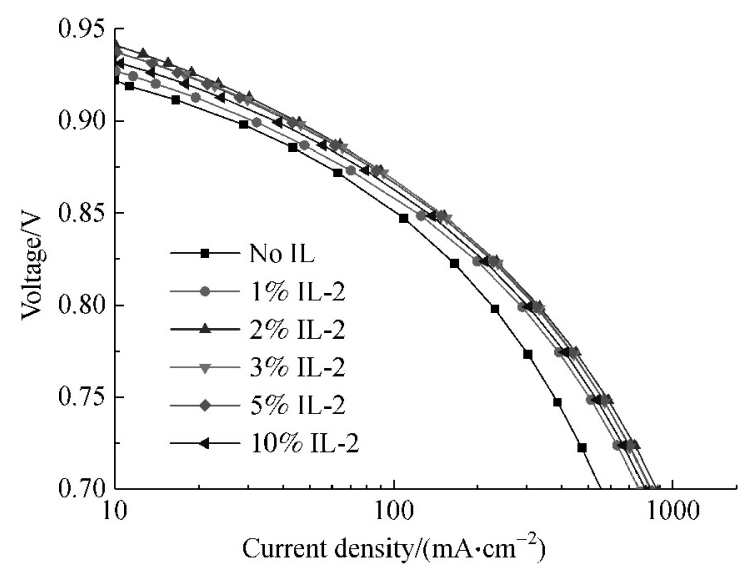

(b)

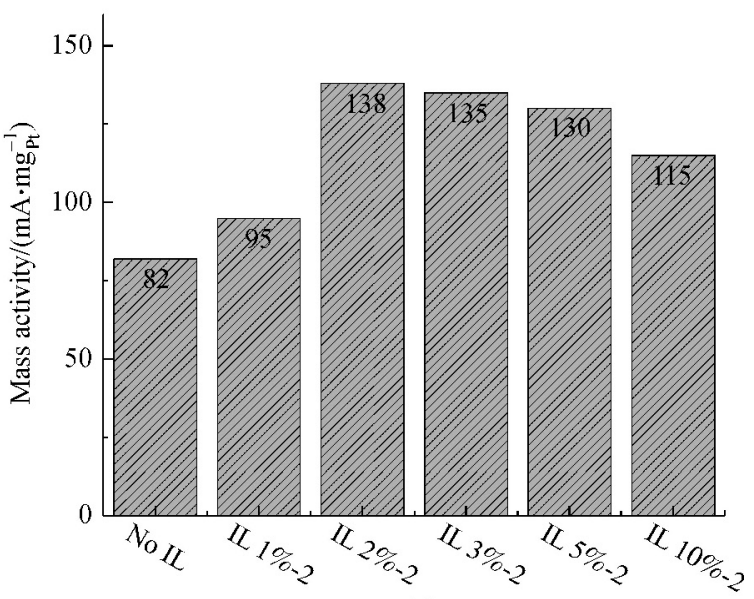

(d)

Fig. 4 (a) CVs, (b) original uncorrected and (c) corrected polarization curves in $\mathrm{H}_{2} / \mathrm{O}_{2}$ for PEMFCs with Pt/C and Pt/C@IL catalysts in cathodes. Test under oxygen was undertaken at $80^{\circ} \mathrm{C}$ with fully humidified gases at $1.5 \mathrm{bar}\left(\mathrm{H}_{2} / \mathrm{O}_{2}\right.$ stoichiometric flows of $\left.\mathrm{s}=2 / 9.5\right)$. The resistance correction voltage was determined via EIS (evaluated at high frequency) vs. current density. Current densities were $\mathrm{H}_{2}$ crossover corrected. (d) shows the mass activities at $0.9 \mathrm{~V}$ for all catalysts obtained by test in MEAs. 


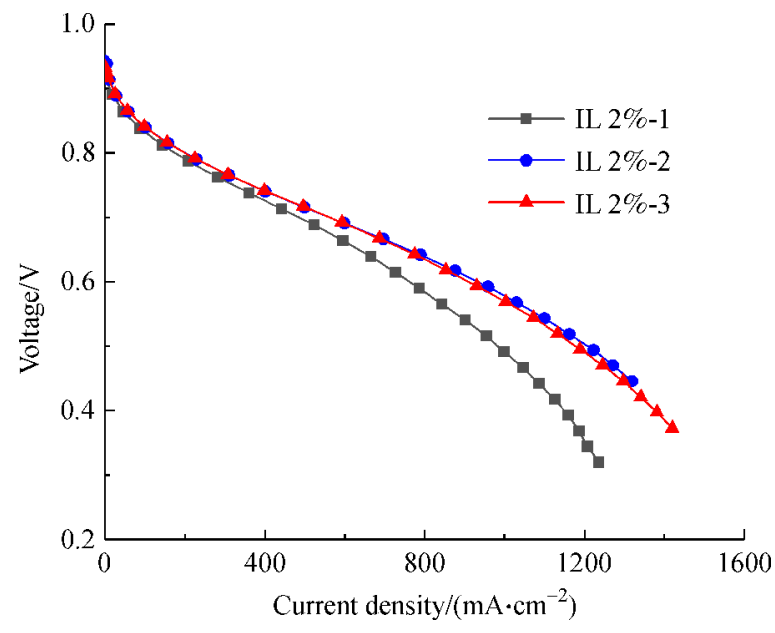

Fig. 5 Polarization curves of PEMFCs with cathodic catalysts modified with $2 \%$ IL $[\mathrm{MTBD}]\left[\mathrm{NTf}_{2}\right]$ for 1,2 and 3 times.

different dimension of pores and the final configuration of IL-metal. Therefore, ethanol was also studied as the adsorption solvent replacing IPA during IL-modification, but IPA is still used as the dispersing media in making catalyst ink for MEA fabrication. The results indicate a different adsorption behavior in ethanol compared to the situation in IPA (Fig. 6). The PEMFC with catalysts modified with a higher IL concentration does not demonstrate better performance. In contrast, the lower IL-initial concentration of $1 \%$ in ethanol overperforms its $2 \%$ counterpart and even $2 \%$ one in IPA, with also a slightly higher electrochemical surface area (ECSA) (Fig. 6(b)) due to the lower IL concentration. We attribute this to dissociation behavior, H-bond effectiveness and mobility of the IL and its components within IL system and around the surface of porous nanoparticles, resulting from the variation of solvability, polarization of the solvents and balance water [17-22].

\section{Conclusions}

The behaviour of IL modification for commercial $\mathrm{Pt} / \mathrm{C}$ catalysts in operating fuel cells was studied in this work. The IL surface modification can improve the catalytic activity towards ORR. The best power density of $0.605 \mathrm{~W} \cdot \mathrm{cm}^{-2}$ was achieved with $2 \mathrm{wt}-\% \mathrm{IL}$ by two times surface modification, which is 1.8 times higher than that of $0.337 \mathrm{~W} \cdot \mathrm{cm}^{-2}$ for unmodified catalysts. However, a higher IL initial concentration formed a large molecular cluster and thick layer on catalyst surface, and in fuel cell operation they partially blocked the pores in catalyst layer resulting in a decreased power performance. The stronger $\mathrm{H}$ bonding and polarity of ethanol facilitated the dissolution and diffusion of the IL further improving the power performance. Comparing with half-cell electrochemical measurement, the results obtained in fuel cells also showed

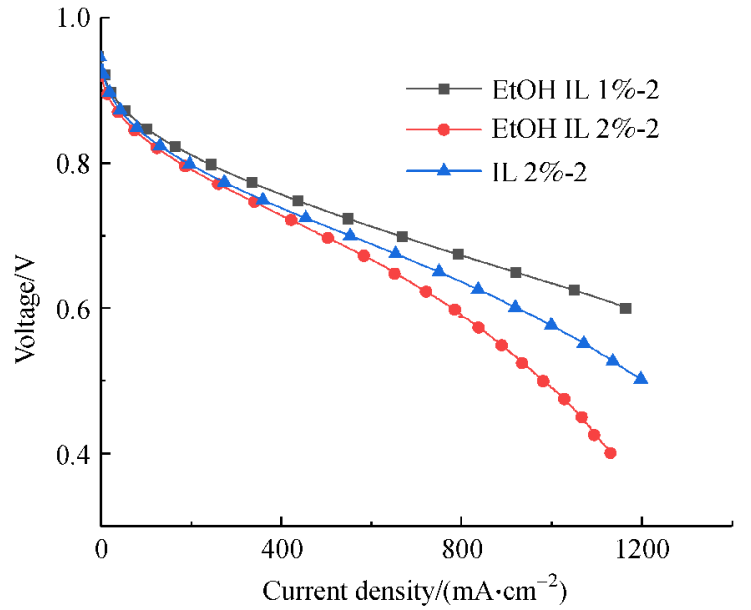

(a)

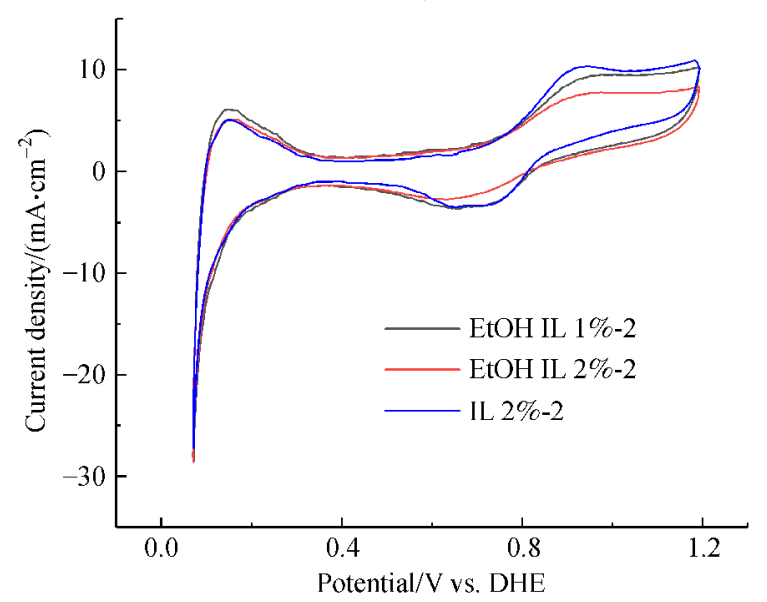

(b)

Fig. 6 Comparison of (a) polarization curves, and (b) CVs for the PEMFCs with cathodic catalysts modified with IL [MTBD] $\left[\mathrm{NTf}_{2}\right]$ dissolved in ethanol and IPA.

a big difference with a much lower optimal IL loading, indicating the different catalyst behavior in the environment for both activity evaluation methods. The fuel cell performance can be further improved by the optimization of the catalyst layer and with further research on ILs.

Acknowledgements Zhang $\mathrm{H} \mathrm{X}$ is funded by EU H2020 Marie Skłodowska-Curie Fellowship (739940). Thanks are also to the support from Guangdong Academy of sciences project (2019 GDASYL-0503005).

Open Access This article is licensed under a Creative Commons Attribution 4.0 International License, which permits use, sharing, adaptation, distribution and reproduction in any medium or format, as long as you give appropriate credit to the original author(s) and the source, provide a link to the Creative Commons licence, and indicate if changes were made. The images or other third party material in this article are included in the article's Creative Commons licence, unless indicated otherwise in a credit line to the material. If material is not included in the article's Creative Commons licence and your intended use is not permitted by statutory regulation or exceeds the permitted use, you will need to obtain permission directly from the copyright holder. To view a copy of this licence, visit http://creativecommons.org/licenses/by/4.0/. 


\section{References}

1. Litster S, McLean G. Review: PEM fuel cell electrodes. Journal of Power Sources, 2004, 130(1-2): 61-76

2. Tokuda H, Tsuzuki S, Susan M A B H, Hayamizu K, Watanabe M. How ionic are room-temperature ionic liquids? An indicator of the physicochemical properties. Journal of Physical Chemistry B, 2006, 110(39): 19593-19600

3. Snyder J, Fujita T, Chen M W, Erlebacher J. Oxygen reduction in nanoporous metal-ionic liquid composite electrocatalysts. Nature Materials, 2010, 9(11): 904-907

4. Snyder J, Livi K, Erlebacher J. Oxygen reduction reaction performance of [MTBD][beti]-encapsulated nanoporous NiPt alloy nanoparticles. Advanced Functional Materials, 2013, 23(44): 54945501

5. Zhang G R, Munoz M, Etzold J M B. Boosting performance of low temperature fuel cell catalysts by subtle ionic liquid modification. ACS Applied Materials \& Interfaces, 2015, 7(6): 3562-3570

6. Zhang G R, Munoz M, Etzold J M B. Accelerating oxygenreduction catalysts through preventing poisoning with non-reactive species by using hydrophobic ionic liquids. Angewandte Chemie International Edition, 2016, 55(6): 2257-2261

7. Lu Y X, Du S F, Steinberger-Wilckens R. Three-dimensional catalyst electrodes based on PtPd nanodendrites for oxygen reduction reaction in PEFC applications. Applied Catalysis B: Environmental, 2016, 187: 108-114

8. Luo H M, Baker G A, Lee J S, Pagni M R, Dai S. Ultrastable superbase-derived protic ionic liquids. Journal of Physical Chemistry B, 2009, 113(13): 4181-4183

9. Gasteiger H A, Kocha S S, Sompalli B, Wagne F T. Activity benchmarks and requirements for Pt, Pt-alloy, and non-Pt oxygen reduction catalysts for PEMFCs. Applied Catalysis B: Environmental, 2005, 56(1-2): 9-35

10. Lu Y X, Du S F, Steinberger-Wilckens R. Temperature-controlled growth of single-crystal Pt nanowire arrays for high performance catalyst electrodes in polymer electrolyte fuel cells. Applied Catalysis B: Environmental, 2015, 164: 389-395
11. Greaves T L, Drummond C J. Protic ionic liquids: Evolving structure-property relationships and expanding applications. Chemical Reviews, 2015, 115(20): 11379-11448

12. Ziyada A K, Wilfred C D. Effect of temperature and anion on densities, viscosities, and refractive indices of 1-octyl-3-propanenitrile imidazolium-based ionic liquids. Journal of Chemical \& Engineering Data, 2014, 59(5): 1385-1390

13. Hayes R, Warr G G, Atkin R. Structure and nanostructure in ionic liquids. Chemical Reviews, 2015, 115(13): 6357-6426

14. Yasuda T, Watanabe M. Protic ionic liquids: Fuel cell applications. MRS Bulletin, 2013, 38(07): 560-566

15. Yaghini N, Nordstierna L, Martinelli A. Effect of water on the transport properties of protic and aprotic imidazolium ionic liquidsan analysis of self-diffusivity, conductivity, and proton exchange mechanism. Physical Chemistry Chemical Physics, 2014, 16(20): 9266-9275

16. Zhang G R, Etzold B J M. Ionic liquids in electrocatalysis. Journal of Energy Chemistry, 2016, 25(2): 199-207

17. Zhang S G, Zhang J H, Zhang Y, Deng Y Q. Nanoconfined ionic liquids. Chemical Reviews, 2017, 117(10): 6755-6833

18. Benn E, Uvegi H, Erlebacher J. Characterization of nanoporous metal-ionic liquid composites for the electrochemical oxygen reduction reaction. Journal of the Electrochemical Society, 2015, 162(10): H759-H766

19. Montiel M A, Solla-Gullón J, Sánchez-Sánchez C M. Electrochemical reactivity and stability of platinum nanoparticles in imidazolium-based ionic liquids. Journal of Solid State Electrochemistry, 2016, 20(4): 1043-1052

20. Saihara K, Yoshimura Y, Ohta S, Shimizu A. Properties of water confined in ionic liquids. Scientific Reports, 2015, 5(1): 10619

21. Babucci M, Uzun A. Effects of interionic interactions in 1,3dialkylimidazolium ionic liquids on the electronic structure of metal sites in solid catalysts with ionic liquid layer (SCILL). Journal of Molecular Liquids, 2016, 216: 293-297

22. Briega-Martos V, Herrero E, Feliu J M. Effect of $\mathrm{pH}$ and water structure on the oxygen reduction reaction on platinum electrodes. Electrochimica Acta, 2017, 241: 497-509 